УДК 378:005.6

\title{
THE ISSUE OF EDUCATION AT A HIGHER ESTABLISHMENT AND SIMULTANEOUS LEARNING A FOREIGN LANGUAGE
}

Dmytruk Veronika, Docent, Associate Professor, Foreign Languages Department, Lviv Polytechnic National University.

ORCID: 0000-0002-3692-7110

E-mail: dmytruk15@gmail.com

Shevchyk Halyna, Master, Department of Applied Mathematics, Lviv Polytechnic National University.

ORCID: 0000-0003-2581-0352

E-mail: halyna.shevchyk.pm.2020@lpnu.ua

The article is devoted to the psychological and pedagogical substantiation of the expediency of learning foreign languages while studying in the institution of higher education. The authors analyse the current educational process in Ukrainian and identify the most important factors influencing the formation of qualified professionals and establish the role of foreign language in each of these factors. It was found that studying can be extremely intensified due to learning a foreign language. It is established that learning foreign languages increases a person's ability to develop intellectually.

Keywords: pedagogical psychology; institution of higher education; foreign language; English language; training intensification; motivation; information management; information gathering; information processing.

\section{ДО ПИТАННЯ ОСВІТИ В ЗВО Й ОДНОЧАСНОГО ВИВЧЕННЯ ІНОЗЕМНОЇ МОВИ}

Дмитрук Вероніка, доцент, доцент кафедри іноземних мов, Національний університет «Львівська політехніка».

ORCID: 0000-0002-3692-7110

E-mail:dmytruk15@gmail.com

Шевчик Галина, магістр, кафедра прикладної математики, Національний університет «Львівська політехніка».

ORCID: 0000-0003-2581-0352

E-mail: halyna.shevchyk.pm.2020@lpnu.ua

Статтю присвячено психолого-педагогічному обтрунтуванню дочільності вивчення іноземних мов під час навчання у закладі вищої освіти. Відзначено, щзо проблематика психологічних труднощів, пов'язаних із вивченням іноземних мов, широко представлена з точки зору педагогічної психології, методології вищої школи у загальних дослідженнях. 3'ясовано, що водночас проблематиці психолого-педагогічних труднощів паралельного опанування обов'язкової програми закладу вищої освіти та вивчення іноземної мови студентами присвячено зовсім мало уваги. Авторами проаналізовано сучасний навчальний процес у закладі вищої освіти та визначено найважливіші фактори, які впливають на формування майбутніх кваліфікованих 
спеціалістів, а також встановлено роль знання іноземної мови в кожному з цих факторів. Виявлено, що прочес навчання може бути надзвичайно інтенсифікований завдяки вивченню іноземної мови. Вивчення іноземної мови забезпечує розвиток тієї частини мозку, яка відповідає за аналітичні здібності. Управління проєктами, написання звітів, рімення технічних проблем $i$ комунікативні навички - лише мала частина тих сфер, де потрібні аналітичні здібності. Зокрема, показано, що англійська мова стає студентам у пригоді в таких видах аналітичної діяльності, як пошук інформації, ї̈ збір, обробка та передача. Знання іноземної мови (а ще краще - декількох) значно збільшуе шанси майбутніх фахівців на працевлаштування в престижних компаніях, так само як позитивно впливає на професіональну конкурентоспроможність між спеціалістами різних галузей. Сучасна політична та соціальноекономічна ситуачія вимагає від студентів вищих навчальних закладів не лише знань іноземних мов, а й сприяє збільшенню вимог до рівня їхньої мовної підготовки, і тому вивчення іноземних мов є рекомендоване для студентів протягом їхнього навчання у закладі вищої освіти. У результаті дослідження виявлено, щчо вивчення іноземних мов підвищує здатність людини до навчання та інтелектуального розвитку.

Ключові слова: педагогічна психологія; ЗВО; іноземна мова; англійська мова; інтенсифікація навчання; мотивачія; управління інформацією; збір інформації; обробка інформації.

In the modern world, where knowledge and technology are updated faster than the life of one generation of people, the educational process should be directed not only to the acquisition of basic knowledge but also to the gaining of needs, skills, and abilities to acquire new knowledge and information throughout the life and use them effectively in practice.

To be able to exchange information, ideas, problems, and ways to solve them, a student must have developed competence in "oral communication". In many kinds of research, it has been shown that learning foreign languages generally increases the communicative abilities of a person, but the issue of the influence of foreign language study on their intellectual development and how the process of mastering a foreign language influence the general progress of students in their studies remains insufficiently investigated.

The problem of psychological difficulties associated with the study of foreign languages is widely presented from the point of view of educational psychology, the methodology of higher education in the studies of modern researchers $[1 ; 2 ; 3 ; 4]$. But at the same time, very little attention is devoted to the problems of psychological and pedagogical issues of the parallel development of the compulsory program of the institution of higher education and the study of a foreign language by students. A need arises for such investigation, which is substantive and topical.

In society, it is believed that education being undergone simultaneously with learning foreign languages interferes and complicates the process of becoming a professionally competent personality in a particular sphere. The aim of this investigation is to explore psychological and pedagogical factors of foreign language learning and their impact on the general progress of a personality obtaining an education at an institution of higher education and make conclusions about the expediency of foreign language learning by students in the institutions of higher education.

Training of competitive, professionally competent experts is a vital task of the Ukrainian educational system, the mission of resistant economic growth, and improving the country's wealth [5, p. 284]. Knowledge today is a capability that a specialist should have. The main goal of higher education is to teach how to study, to teach in a way that graduates can get a job and adapt to new requirements.

Competence determines the capability to make rational decisions in complicated 
difficulties using knowledge, skills, and techniques acquired during studying. The competence method is essential because it converts the process of gathering certain knowledge, skills, and techniques into forming and developing a student's ability to act practically in different situations by applying the acquired knowledge and experience [6, p. 201].

Nowadays, one of the most important competencies of a specialist in any field is managing information. It means the ability to find, choose, and evaluate information from different resources and to link it to other information, critically evaluate its actuality and quality.

In general, all information is processed by a series of processing systems, for example, perception from the environment, attention (ability to focus), short-term memory. For instance, the human eye receives visual information and codes information, like a computer, into electric neural activity. Then it is fed back to the brain where it is stored. This coded and stored information can be used by brain parts relating to mental activities such as attention, perception, and memory. As a result, the output behavior might be, for example, to read what you can see on a printed page. Therefore, behavioral responses result from using "mental programs," which store, retrieve, and transform information.

Nowadays, psychologists are into investigations about phenomenon of focusing on to one thing rather than another, as known as selective attention. When people selectively attend to one activity, they tend to ignore other stimulation. Curiously, why sometimes we switch our attention to something unattended previously, or, it is also interesting so called an attention capacity, i.e. the number of things which we can attend to at the same time. In the 1950s, Broadbent adopted a model of the brain to be a limited capacity information processing system [7]. So, one way to make sense of attention is to think of people as information processors who can only process a limited amount of information at a time without overloading it.

Information processing means the detectable change of information, the process that describes everything that happens in the environment. According to McLeod, the principle of representation of the individual as a processor of information lies in the basis of cognitive psychology [8]. Sometimes, an information processor changes the form of presenting the inputted information. We have another definition, made by Claude E. Shannon, who defined processing of information as conversion of latent information into manifest information clear, understandable to all [9].

There are five sensory registers: tactile, visual, auditory, taste, and olfactory. These senses are all present since birth and are able be engaged simultaneously. Behavioral response of the sensory register is very short (around 1-3 seconds), but it has a large capacity. This phenomenon is compared by R. Sternberg to taking a photo with a flash. After the flash goes off, for a few brief moments it seems to still be there. Nevertheless, the flash is soon gone and there is no opportunity to know was it there or not. Images or information based on meaning are stored in short-term memory as well, but it decays without rehearsal or repetition of such information. On the other hand, long-term memory has indefinite duration and an unlimited capacity. Despite the fact, sometimes it is difficult to access some information; it might become forgetful or feel as if the information is on the tip of the tongue [10, p. 50].

Let us define what information gathering is. Information gathering helps the individual and the organization to undertake complicated tasks that would otherwise be extremely hard to accomplish, if not impossible, without the benefit of gathered information. As defined in 
the dictionary [11, p. 271], information gathering is the act of collecting information from various sources through various means.

In the literal sense, information gathering is a basic human skill necessary for undertaking basic human activities such as eating, sleeping, working, etc. To eat, one must know if the food is edible or not; to sleep, one must know if the sleeping place is comfortable.

However, being applied to business and other specialized organizations (scientific, military, academic), information gathering is an advanced skill that requires the training and education of personnel in the procedures and methods of gathering information from sources that are of a higher level than ordinary sources. In the case of interviewing personalities, for example, a researcher usually gets to interview authorities and proper officials. Thus, he must know the proper ways to address distinguished personalities of the community and society in general.

In general practice, information gathering is collecting data for dealing with the individual's or the organization's current situation. More data means more and better ways of dealing with the current situation. More data broadens the minds of those who will use the data to solve current organizational problems. New ideas come more easily if there are lots of facts to be used as bases.

There are two main types of sources in the field of information gathering. They are existing sources and natural sources. Existing sources are those sources of information that can be found in the printed, video, audio and other materials that are available to the public or upon request to proper bureaucracy. Natural sources are first-hand sources such as those who have tried products, services and methods, and expressing their experience and opinions to the researcher.

In order to implement a good information gathering design, a step-by-step approach is advisable for any researcher to follow. It occurs in six steps.

1. Analyzing the problem. The researcher needs to identify the purpose and the process of the research he is doing. For who is he doing it and why? These questions and more need to be answered right at the start of the research.

2. Identifying the sections of the information gathering. Before going through the process of information gathering, a sectioning of the general outline of the task can be helpful. Sections such as those classifying the recipients of the data, the detailing of the specific questions that need to be answered, and also the setting of the knowledge levels of the team members involved facilitates an easier to follow research program.

3. After the outline of the research task, the researcher may then set the actual plan of activities needed to carry out the information gathering tasks. Questions such as: Where to go for the research? What materials need to be invested in? What skills are needed to be implemented?

4. The tools that are involved in information gatherings such as data storage devices and publications have their own set of required skills that the researcher must readily possess or is capable of having. Languages contained in publications could pose a problem, and data storage devices could have proprietary names. And names, as we all know in the computer industry, means lots of adjustments.Begin the gathering. During the gathering of the data, the researcher encounters various relevant or non relevant to the present subject information. $\mathrm{He}$ must sift through all of these carefully.

5. Review and record the data obtained. A recording that includes everything from 
the start to the end of the gathering process must be set in writing to provide all the information that the organization needs.

The process of learning a language is already a creative stage of personal development and it contributes to the cultural and professional development of each member of society because the principle of comparing cultures and professional achievements of different peoples contributes to an analytical understanding of the role and place of each member of society intercultural/interethnic communication.

To be able to transfer information, ideas, problems, and ways to solve them, a student must have developed competence in "oral communication". Learning foreign languages generally increases the ability of a person to study and intellectually develop. It has been experimentally proven that developing analytical abilities while mastering a foreign language positively affects mathematical and communicative abilities.

According to the latest research of British scientists, learning the second language provides development of the part of the brain that is responsible for speech speed. The student not only tells about something, but he also expresses and argues his opinion and his attitude to the subject of communication [12, p. 475].

The main is that you have not so many articles, books, and other theoretical resources in the native language during your study, for example, in Ukrainian. In contrast with, for instance, English, because the English language is common worldwide. Thus if you know this foreign language, you have access to an inexhaustible source of information.

Adequacy of exercises means observing that type of speech activity that a student is developing at a certain lesson. The search and research exercises take a leading place. Expressing the opinion on a certain topic positively impacts the development of student skills to conduct a dialogue: the volume and the pace of speech are increasing, the student initiative and their emotional response of their expressing, etc.

While someone is expressing their opinion on a certain topic, it is good to allow other participants to express themselves. Any listener may comment on the papers after the first speaker's speech to supplement or deny the speech or voice their opinion on the problem under consideration. If they are against the ideas presented by a speaker or think that they are mistaken, they can ask the chairman (if it is) to give them the floor to clarify their point of view or express their disagreement offering convincing arguments.

In addition, ways of learning such as crossword puzzles, where students find hidden words and terms; questions and answers with elements of discussion; activation of students' communication skills by substantiating their own opinion; presentation of own scientific and creative searches as reports at conferences and other events helps in learning a foreign language.

Therefore, if you defend your diploma in English, it is a great privilege because then, if you enter the master's degree, you will get extra points while entering the Ukrainian university. Moreover, diplomas of almost all Ukrainian universities defended in English are also legally recognized abroad. Therefore, if there is a goal to study abroad, then defending a diploma in English will be a good practice in this foreign language and give more chances for successful entry abroad.

Nowadays, there is a need for effective study and perfect mastery of foreign languages due to many factors, including partnership and interactions with other states, socio-economic transformations, rapid scientific and technological progress, travel to different countries, etc. 
Undoubtedly, knowing a foreign language is a necessary component of human success both in the professional sphere and in terms of their intellectual and cultural development.

The training of a prospective expert who can carry out successfully professional and further study process after graduation and who has the competencies in a certain area of knowledge for a certain qualification and ideological, moral, and ethical qualities as well as social qualities largely depends on professional teacher's competence.

Teachers have a task to make conditions for the growing generation for its maximal self-determination and self-expression. The main purposes of our teachers are training competitive graduates, adapted to information society that is improving rapidly, providing a high level of knowledge and skills for further professional grows of students.

The language teacher promotes personal examples in intercultural/interethnic communication by presenting an appropriate speech culture to improve speech competence in native and foreign languages and helps students overcome difficulties in mastering a foreign language skillfully and unobtrusively. Language learning is a continuous creative process reflected in the student's ability to communicate with native speakers and contributes to the mutual satisfaction of recipients.

The main goal of the teacher is not only to provide students with quality knowledge but also to create the necessary conditions to enhance students' cognitive activity, to arouse interest in learning a foreign language, motivate them to be modern, competent, and knowledgeable because it will promote intercultural communication and open good prospects for employment. The teacher should use the following methods for achieving this goal:

1. Meetings with graduates who can prove by example that knowledge of a foreign language is critical in today's world and contribute to success in the professional field.

2. Creating an environment where foreign language proficiency is greatly appreciated and considered a prestigious prerogative and students would have real opportunities to improve their knowledge.

This can be achieved through, for example, the presence of volunteers from foreign countries, with whom students would be able to communicate and spend time, perhaps even outside the school. Such a situation would show the need for a foreign language in practice, would arouse the thirst for knowledge and the desire to master the language at a high level.

3. Involve students in educational conferences with representatives of other countries so that children have the opportunity to learn about cultural differences and living conditions of different nations, compare their views and attitudes to certain issues, create dialogue and discuss issues, learn to lead discussions, be aware of the latest developments in the world, science, economy, etc.

For example, the latter method in the educational process requires the use of information technology. Indeed, it is not easy to imagine a modern lesson without the use of computers, laptops, or a multimedia board, as well as a modern teenager without a mobile phone in hand. So, without a doubt, a lesson accompanied by the latest technology will interest the student more than a lesson with the usual traditional forms of teaching [13, p. 37].

For effective teaching of a foreign language, teachers try to use the latest methods. We will divide the means of teaching a foreign language into tangible and intangible. Intangibles include the teacher's word and tangible ones: technical teaching aids (TV, computer, film, and slide projectors, multimedia board, video and audio recordings, movies, etc.); electronic textbooks; computer programs; literary sources (educational, methodical, and reference 
literature); Internet resources (training and search programs) and visual material (illustrations, drawings, reproductions of paintings, diagrams, tables, cards for individual work, posters, handouts, etc.). Foreign language teaching aids do not contradict, closely complement each other, and are used together with other components of the learning process [14, p. 23].

The use of such an additional teaching tool as a computer makes it possible to create an information environment that motivates students to master a foreign language and maintain the interest and activity of students throughout the learning period. However, such an option is unrealistic to be realized in the absence of access of the device to the Internet. The Internet is a global computer network that operates on standardized protocols and connects more than 50,000 networks [11, p. 279].

Today, thanks to the global network, both students and teachers can use this or that necessary educational resource anytime and anywhere on the planet. Learning can be mobile, as a form of distance education has emerged. There are also many online courses from the world's leading universities that are open and accessible to users. Typically, educational sites offer training in four types of speech activities, namely: writing, listening, reading, speaking, and also include exercises on grammar, phonetics, and vocabulary of a foreign language. Prospective teachers make full use of the latest educational tools, such as blogs, Wikipedia, podcasts, various learning platforms, audio, and video materials, because they understand their effectiveness and ease of use. With the help of these interactive tools, the educational process becomes up-to-date [15, p. 173].

Additional teaching aids also include electronic textbooks [13, p. 35], which systematically contain a large amount of theoretical and illustrative material, and audio books, which can be listened to at any convenient time on a mobile phone or portable mp3 player. Nowadays, you can find many sites full of useful information for teachers. There are actually educational and information sites. Special educational sites teach different levels of exercises and tasks to develop any learning skills of students. Thanks to information sites, you can find interesting information, creative tasks; find additional material that students would love to work with in class [15, p. 176].

The first includes educational and methodological complexes (EMC). The EMC contains a set of the following components: a book for teachers, a book for students, a workbook, program, audio, and video materials [13, p. 41], the second contains various aids such as handouts, special audio, and video materials, games, cards, illustrations, songs, poems, etc. Teaching aids help students to perceive, memorize new material, train and apply it. They facilitate the teacher's activities, for example, the explanation of a new topic, its consolidation, systematization, revision, and control. In other words, they contribute to the effective conduct of the educational process.

In the pedagogical activity process, teachers have concluded that brainstorming, business games, disputing, pieces of training, analysis of concrete situations, independent study, and participation in seminars contribute to forming a creative personality. Intellectual student activity teaches to predict, research, and check the correctness of made decisions and hypotheses, educate culture of communication, form the skill to work in a team and with a team.

It should be mentioned that a vital skill for today's professional activity is the ability to cooperate in a team (form the skill to work in a team and with a team), coordinate solving of tasks and problems. So, it will be relevant to create own projects, hold conferences, round tables, debates. Professional confidence and student competence should be formed with the 
help of project education, making up real situations, holding excursion on production.

Practical training creates conditions for the enrichment of life experience, expansion of social contacts of the graduate, formation of skills of self-management. The professional competencies of the future specialist should be formed in a university. However, their further level can rise only in the process of professional activity.

The success or failure of students in learning a foreign language depends not only on the means of learning but also on their motivation. The problem of learning motivation is considered one of the main in pedagogy because the effectiveness of learning depends on the interest and involvement of students in the learning process. According to the American scientist R. Gardner, motivation is one of the most important factors influencing mastering a foreign language. He believes that language learning strategies are unlikely to work if a person is not motivated to learn a language [16].

Thus, learning motivation is a complex system of motivations (motives) that force to act on somebody to achieve their aims. Distinguish between integrated and instrumental, relevant and irrelevant, positive and negative motivation. In pedagogy, there is also the concept of motive. Motives answer the question: "why study?". We found that the most productive are internal motives, which reflect the personal level of regulation of educational activities (self-regulation), and professional motives, which create a relationship between educational activities and future professional activities [14].

To sum up, we refute completely some existing beliefs that parallel education and learning a foreign language complicate study and becoming a professionally competent personality. Moreover, we have proved by facts that the process of education can be enormously enhanced by learning a foreign language. We have identified some of the most important factors that affect the formation of prospective qualified specialists and the role of knowing a foreign language in each of those factors. They are the following: professional competence of teachers, cognitive interest and special abilities of the student, practical training, forms and methods of teaching (material and technical base of the university), motivation.

Learning foreign languages generally increases the ability of a person to studying and intellectual development. Studying a foreign language provides the development of the part of the brain that is responsible for mathematical and communicative abilities.

An issue that greatly contributes to students' desire to learn foreign languages is the availability of information sources. For example, during a pandemic, when there is limited access to libraries, students do not have so many articles, books, and other sources in the native language (for example, in Ukrainian) being provided on the Internet on the contrary with the English language. The reason is that English is one of the topmost common languages all over the world. Therefore, if you know at least English, you have access to an inexhaustible source of information, and this reason contributes to your success in education. Moreover, these opportunities expand when you know more foreign languages. And also, we should not forget about employment opportunities, which grow significantly when you have a good command of foreign languages. As a result, the knowledge of a foreign language also contributes to the personal cultural development of each member of society. Furthermore, the principle of comparative cultures and the professional achievements of various peoples contribute to understanding the role and place of each member of society.

We have a good recommendation for those students who may not believe in all of the 
above-mentioned. Test yourself learning a foreign language simultaneously with studying and you will personally receive proof of the effectiveness of this method of development of your professional competencies by yourself and get many pros.

As areas for further research, the research of self-guided work of students in a distant form of a foreign language learning in higher educational institutions can be identified.

\section{СПИСОК ВИКОРИСТАНИХ ДЖЕРЕЛ}

1. Stengel E. On Learning a New Language. International Journal of Psycho-Analysis. 1939, No. 20. P. 471-479.

2. Linguistic Perpectives on Second Language Acquisition. / S. M. Gass (Ed.) et al., Cambridge University Press, 1989. Doi: http://dx.doi.org/10.1017/CBO9781139524544.

3. Tsai-Yu Chen, M. A, Goretti, B. Y., Chang, M. A. The Relationship between Foreign Language Anxiety and Learning Difficulties. Foreign Language Annals. 2004. Issue 37 (2). P. 279-289. DOI: 10.1111/j.19449720.2004.tb02200.x

4. Bley-Vroman R. What is the logical problem of foreign language learning? Linguistic Perspectives on Second Language Acquisition. S. M. Gass (Ed.). Cambridge University Press, 1989. Chapter 2. P. 41-68.

5. Kuzmin O. Y., Tsehelyk G. G., Yastrubskyy M. Y., Stanasiuk N. S., Synyutka, N. G. Economic and mathematical modeling of management processes and financing the training of specialists by higher educational institutions. Mathematical Modeling and Computing. 2020. Issue 7(2). P. 278-284. DOI: $10.23939 / \mathrm{mmc} 2020.02 .278$

6. Мокін Б. І., Мізерний В. М., Мензул О. М. Формування професійної компетентності студентів в умовах професійно-практичної підготовки. Вісник Вінницького політехнічного інституту. 2011. Вип. 5. С. 199-203.

7. Broadbent D. E. A mechanical model for human attention and immediate memory. Psychological Review. 1957. Issue 64(3). P. 205-215.

8. McLeod S. A. Bruner. 2008. Retrieved from www.simplypsychology.org/bruner.html

9. Shannon C. E., Weaver W. The Mathematical Theory of Communication. 16th Printing Edition. The University of Illinois Press. 1971.

10. Kaufman J. C. The Essential Sternberg: Essays on Intelligence, Psychology, and Education. E. L. Grigorenko (Ed.). 1st edition. Springer, 2008.

11. Англо-український тлумачний словник з обчислюваної техніки, Інтернету і програмування. / під ред. Е. М. Пройдакова, Л. А. Теплицкого. 1-е вид. Київ: Видавничий дім «Софт Прес», 2005. 756 с.

12. Kennedy T. J. Language Learning and Its Impact on the Brain: Connecting Language Learning with the Mind Through Content-Based Instruction. Foreign Language Annals. 2006. Issue 39(3). P. 471-486. doi: 10.1111/j.1944-9720.2006.tb02900.x

13. Williamson B. (2016). Digital methodologies of education governance: Pearson plc and the remediation of methods. European Educational Research Journal. 2016. Issue 15(1). P. 34-53. doi: 10.1177/147490411 5612485

14. Методика навчання іноземних мов у загальноосвітніх навчальних закладах: підручник / Л. С. Панова та ін. Київ: Академія, 2010. 328 с.

15. Костенко І. Г. Використання Інтернет-ресурсів на уроках англійської мови. На допомогу педагогу: Таврійський вісник освіти. 2013. Вип. 1(41). С. 170-176.

16. Gardner R .C. Motivation and second language acquisition: The socio-educational model. New York: Peter Lang, 2010. doi: doi.org/10.14746/ssllt.2012.2.2.5.

\section{REFERENCES}

1. Stengel, E. (1939). On Learning a New Language. International Journal of Psycho-Analysis, 20, 471-479.

2. Linguistic Perspectives on Second Language Acquisition. S. M. Gass (Ed.) et al. (1989), Cambridge University Press. doi: doi.org/10.1017/CBO9781139524544

3. Tsai-Yu Chen, M. A, Goretti, B. Y., Chang, M. A. (2004). The Relationship between Foreign Language Anxiety and Learning Difficulties. Foreign Language Annals, 37(2), 279-289. doi: 10.1111/j.19449720.2004.tb02200.x

4. Bley-Vroman, R. (1989). What is the logical problem of foreign language learning? Linguistic Perspectives

\section{ISSN 2307-4906}


on Second Language Acquisition. S. M. Gass (Ed.). Cambridge University Press, ch. 2, 41-68.

5. Kuzmin, O. Y., Tsehelyk, G. G., Yastrubskyy, M. Y., Stanasiuk, N. S., Synyutka, N. G. (2020). Economic and mathematical modeling of management processes and financing the training of specialists by higher educational institutions. Mathematical Modeling and Computing, 7(2), 278-284. doi: 10.23939/mmc 2020.02.278

6. Mokin, B. I., Mizernyi, V. M., Menzul, O. L. (2011). Formuvannia profesiinoi kompetentnosti studentiv v umovakh profesiino-praktychnoi pidhotovky. [Formation of professional competence of students in terms of professional and practical training]. Visnyk Vinnytskoho politekhnichnoho instytutu - Gazette of Vinnytsia Polytechnic Institute, 5, 199-203 [in Ukrainian].

7. Broadbent, D. E. (1957). A mechanical model for human attention and immediate memory. Psychological Review, 64(3), 205-215.

8. McLeod, S. A. (2008). Bruner. URL: www.simplypsychology.org/bruner.html

9. Shannon, C. E., Weaver, W. (1971). The Mathematical Theory of Communication. The University of Illinois Press.

10. Kaufman, J. C. (2008). The Essential Sternberg: Essays on Intelligence, Psychology, and Education. E. L. Grigorenko (Ed.). Springer.

11. Anhlo-ukrainskyi tlumachnyi slovnyk z obchysliuvanoi tekhniky, Internetu i prohramuvannia. (2005). E. T. Proydakov, L. A. Teplitsky (Eds.). Kyiv: Vydavnychyi dim "Soft Pres" [in Ukrainian].

12. Kennedy, T. J. (2006). Language Learning and Its Impact on the Brain: Connecting Language Learning with the Mind Through Content-Based Instruction. Foreign Language Annals, 39 (3), 471-486. doi: 10.1111/j.1944-9720.2006.tb02900.x

13. Williamson, B. (2016). Digital methodologies of education governance: Pearson plc and the remediation of methods. European Educational Research Journal, 15(1), 34-53. doi: 10.1177/1474904115612485 doi.org/10.1177/1474904115612485

14. Metodyka navchannia inozemnykh mov u zahalnoosvitnikh navchalnykh zakladakh: pidruchnyk. L. Panova (Ed.) et al. (2010). Kyiv: Akademiia [in Ukrainian].

15. Kostenko, I. H. (2013). Vykorystannia Internet-resursiv na urokakh anhliiskoi movy. Na dopomohu pedahohu: Tavriiskyi visnyk osvity - To help the teacher: Taurian Bulletin of Education, 1(41), 170-176. [in Ukrainian].

16. Gardner, R. C. (2010). Motivation and second language acquisition: The socio-educational model. New York: Peter Lang. doi: doi.org/10.14746/ssllt.2012.2.2.5. 